\title{
The Analysis of UK and US Migration Policies in Relation to the Middle East Countries
}

\author{
Aleksander Eremin \\ The faculty of intercultural communications and \\ international relations \\ Belgorod National Research University \\ Belgorod, Russia \\ master.gothic@yandex.ru
}

\author{
Irina Kuprieva \\ The faculty of Linguistics \\ A.S. Griboedov Institute of International Law and \\ Economics \\ The School of Education \\ Far Eastern Federal University \\ Moscow, Russia \\ kuprieva@yandex.ru
}

\begin{abstract}
Of course, the influx of migrants to the countries mentioned above comes not only from the Middle East and not only to the UK and the US, but as part of this study, we are interested particularly in the problem of the interaction of the Arabic-speaking and English-speaking peoples.

The article analyzes the current situation in the field of migration policy in the United States and Great Britain, as well as the circumstances that led to this. Analysis data may be used to better understand the situation of immigrants from Arab countries to countries where the official language is English.

This article discusses the main problems and aspects of state migration policy of the USA and Great Britain, regarding the countries of the Arab world. The US and the UK are undoubtedly one of the leaders in economic development in North America and Europe, respectively. Therefore, the fact that they attract hundreds of thousands of migrants every year is a logical consequence. However, this is not the only reason for the relocation. The unstable political situation and military conflicts in the Middle East are forcing people to leave their home countries. They fear for their lives and the lives of their loved ones. This issue has become especially relevant in recent years with the intensification of the conflict in the Middle East.
\end{abstract}

Keywords: migration, MENA region, the UK, USA, Arab migrants, migration policy, Middle East

\section{INTRODUCTION}

In the modern world, with its tendency towards multicultural society, the average person finds it much easier than before to change his permanent place of residence and become a resident of another country. Some countries welcome this and build their migration policies in such a way as to attract as many immigrants as possible. Other countries are ready to provide a migrant with a residence permit, but only if such a person will have education and qualifications in specific areas which are useful to this society. However, there are also such countries, the flow of migrants (including unskilled ones) to which is so great that it begins to threaten not only cultural identity, but also the safety of people who originally lived in these territories due to the emerging social tension.

In the article, we will try to analyze this problem using the example of the United States of America and Great Britain as continental leaders in terms of the number of incoming migrants, and consider their situation with migrants from the Middle East, particularly. As part of our research, we are interested in exactly how Arabic-speaking peoples coexist, assimilate, and live in an English-speaking environment.

\section{LITERATURE REVIEW AND RESEARCH METHODS}

As a research base for this article, we used mass media news articles, open government sources of migration law in the United States and Great Britain, as well as literature from various authors dealing with this topic.

In particular, some of the statistical information used in this article was borrowed from the website migrationobsevatory.ox.ac.uk for the UK data [1]. This source is supported by Centre on Migration, Policy and Society (COMPAS) at the University of Oxford. Similar statistics data for the United States was taken from the article by Mattea Cumoletti and Jeanne Batalova from Migration Policy Institute. The article is called "Middle Eastern and North African Immigrants in the United States" [2]. The basic works were used in the analysis of the topic are following: "The Arabs: A History" by Eugene Rogan [3]., an American historian of the Middle East and North Africa from the late Ottoman era to the present. This book named one of the best books of 2009 by The Economist, The Financial Times, and The Atlantic Monthly; "The Arab Americans: A History" by Gregory Orfalea [4]. The book is based on interviews with 140 Arab Americans and considers Arab immigration to the 
Islam in Britain is the second largest religion by the United States since the mid-19th century, their arduous journey to this country and their attempt to incorporate their new American identity with their Arab heritage. The analysis of British Migration Policy was mainly based on articles: "Arab engagement in the British general and local elections" by Susannah Tarbush [5], "Study for consideration of inclusion of "Arab" as an ethnic group on ethnicity profile forms", and the $\mathrm{PhD}$ thesis "The formation and development of Muslim communities in Great Britain: the second half of XX - beginning of XXI centuries" by Asiyat Ayupova [1].

The goal of considering this topic is to trace the historical premises of interaction of Arab native speakers and English native speakers. This issue is a part of our research on Arabic loan words in English.

The main used research methods: abstracting, analysis and synthesis method, historical method.

\section{RESULTS}

Great Britain today is one of the leading places in Europe in terms of the number of migrants entering. In general, the immigration cluster of the UK population today is quite diverse and can be represented by the following groups [6]:

- Arriving from European countries that became full members of the European Union in 2004

- Foreign students

- Citizens fleeing persecution in their homeland

- Non-EU citizens (Africa, Asia, Australia, New Zealand)

In 1997, when the Labor Party, led by Tony Blair, came to power, net immigration amounted to 107 thousand people a year, and in 2007, it reached 330 thousand people a year. Between 1997 and 2007 net immigration amounted to 3 million people, equivalent to $5 \%$ of the UK population. About two-thirds of them are not citizens of the European Union [7].

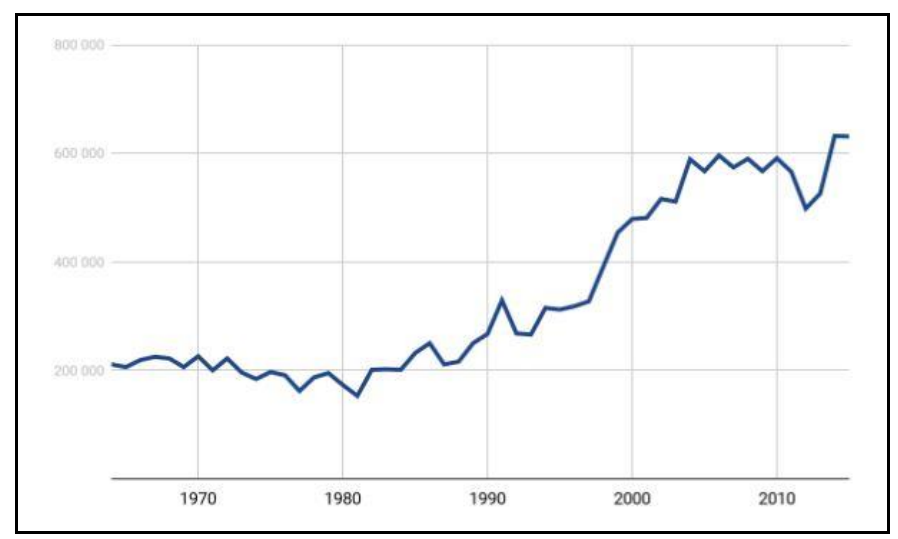

Fig. 1. International migration to the UK (1946 - 2015)

In the year, ending December 2018: 602000 people migrated into the UK and 343,000 people emigrated from it, leaving a net migration figure of $+258,000$. This represents the balance of long-term migrants moving in and out of the country [8]. number of adherents. According to the 2011 census, the number of Muslims living in the United Kingdom reached 2.7 million or $4.8 \%$ of the total population. This value is almost two times higher than in 2001 [17].

In fact, England has long-standing ties with the Arab and Muslim world. Many of its former colonies are inhabited by Muslims, who began to arrive in the capital of the (former) British Empire, in the second half of the XIX century. The first mention of the Muslim community in London dates back to the 90 s of the 19 th century.

At that time, an official Muslim organization emerged in East London, which adapted the three buildings on the 1'st Commercial Road for houses of worship. In addition, the first real mosque appeared in the British capital in 1899.

According to the documents of those years, the sailors of the British merchant fleet, originally from Somalia and Yemen played the main role in its construction,

In the 30s of the 20th century, Britain, and in particular London, was again covered by a wave of Arab-Muslim migrants, now from Iraq. In the 50s, there were Moroccans who settled mainly settled in North Kensington and the East End.

In the 70s, the first Arab guide to London was published, but it contained information not only about the Arab, but also about other Muslim communities of the city, because the most numerous of them are still Pakistani, Turkish and the community of immigrants from Bangladesh (former territory of British India).

Most of the Arab immigrants come from Morocco, Algeria, Iraq, Egypt, Yemen, Sudan, Lebanon, West Africa, Libya, Tunisia, Saudi Arabia, the UAE, Syria, Jordan, Palestine, Oman and Qatar [9].

Mostly Arabs are engaged in retail and wholesale, restaurant and hotel business, financial (especially money transfers), transport and medical services. Most of the religious Arabs are Muslims, the rest are Christians [10].

According to the results of a sociological study published in 2014, Muslims face growing discrimination in the country's labor market and have minimal chances of gaining managerial positions. Because of the growing Islamophobia and hostility of Muslims, they are collectively referred to the lower stratum of the country's racial and ethno-cultural system. Muslims are perceived as a threat. The probability of getting any job is 76\% lower for a Muslim than for white-skinned British Christians of a similar age group and qualification. Muslim women have $65 \%$ lower chances of employment than Christian women [11].

According to the country's Interior Minister Sajid Javid, after Brexit, the British Ministry of Internal Affairs will carry out the migration system reform, including toughening the border pass regime and the introduction of new visas for labor migrants.

According to published documents, in general, the British migration system will be tightened. The authorities plan to 
the extent necessary to maintain the required balance in the national labor market.

The Arab migration to the US began at the end of the 17th century. Mostly it was immigrants from the Ottoman province of Syria (modern Israel, Lebanon and Syria) [3]. People were driven by worsening economic conditions and continuous wars. By the first quarter of the 20th century America became home to at least 50 thousand people from the Middle East and North African (MENA) region. Most of them were not educated well and occupied low-paid positions. Among the immigrants there were a small number of highly educated Arabs, inspired by the American ideas of freedom and democracy and who decided to settle in a country where they could achieve the greatest self-realization [1].

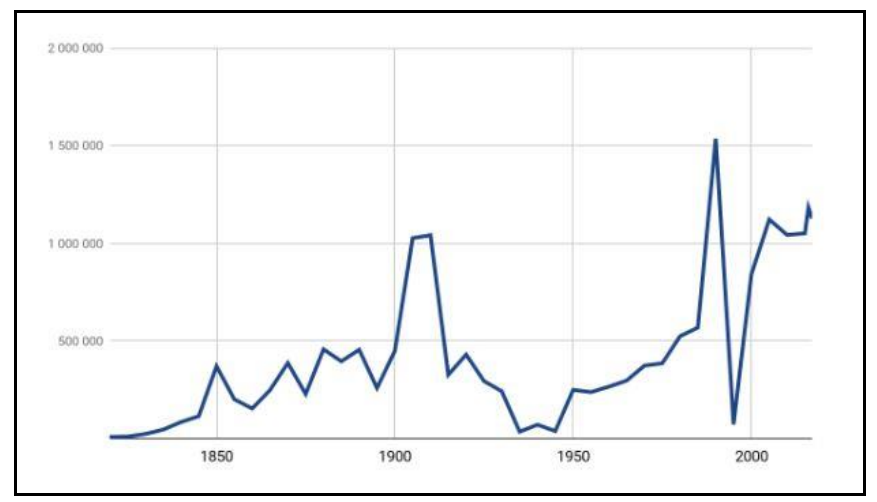

Fig. 2. Official migration statistics in the United States (1820 - 2017)

The reduction in the number of Arab immigrants coming to the United States occurred during the First World War and was related to the tightening of US migration legislation. Adopted at the beginning of 1917, the Immigration Act, also known as the Asiatic Barred Zone Act was directed mainly against East Asian migrants, but also affected Arabs. Since in accordance with this act, the Middle East was included in the zone, the entry of immigrants to the United States from these countries was complicated. Four years later, in 1921, the new Immigration Act reduced the number of migrants who may come to the United States within a year to $3 \%$ of the total number of immigrants from that country already in the United States. In 1924, this quota was reduced to $2 \%$ [16]. The reason for the tightening of migration legislation was the policy of isolationism, which has gained popularity in the United States since the end of World War I. The Americans did not want to be involved in world events and take actions in the international arena that could drag them into a new world war [17].

After a significant decline in Arab immigration of the 20s -40 s of the 20th century, a new increase in the number of Middle East immigrants arriving in the United States followed the end of World War II and the liberalization of migration legislation that began after it. Unlike the first wave migrants, the majority of the new ones were Muslims, although a certain proportion of Christians were still present in this stream. In addition to the usual economic motives related to finding a job and improving living conditions, many of the new immigrants decided to change their place of residence for political 


\section{CONCLUSION}

reasons. The most serious political turmoil in the region, such as the Arab-Israeli wars of 1948, 1967 and 1973, was certainly accompanied by a sharp increase in the number of Arabs seeking to settle in the United States [18]. Many new Arab Americans began their lives in the United States as a student, and upon graduation decided not to return to their homeland, but to remain in the United States on an ongoing basis. Some of them justified their desire to obtain American citizenship with the fear of political repression that they might suffer if they returned home.

At the turn of the 20th and 21st centuries, the share of Arabs in the total number of immigrants to the United States was about $4 \%$. This ratio remained almost unchanged even after the September 11, 2001 attacks, despite expectations that the flow of Arab migrants to the United States would drop sharply or stop at all [19]. However, this did not happen. The only area where the share of Arab migrants fell sharply after the events of 2001 was education. A serious tightening of security measures in the country caused a significant decrease in the number of young Arabs coming to the USA on student visas. The adoption of the Patriotic Act, which provided the American security services with the opportunity to strengthen control over citizens, as well as over persons located in the United States, also tightened the rules for obtaining entry visas, which primarily affected immigrants from the Arab East. One way or another, the influx of immigrants from the region continues and, according to the Washington-based Institute for Migration Policy, in 2009 the number of Arab immigrants (i.e. people born in a particular Arab country and then moved to the United States in order to obtain American citizenship) amounted to 830 thousand people [16].

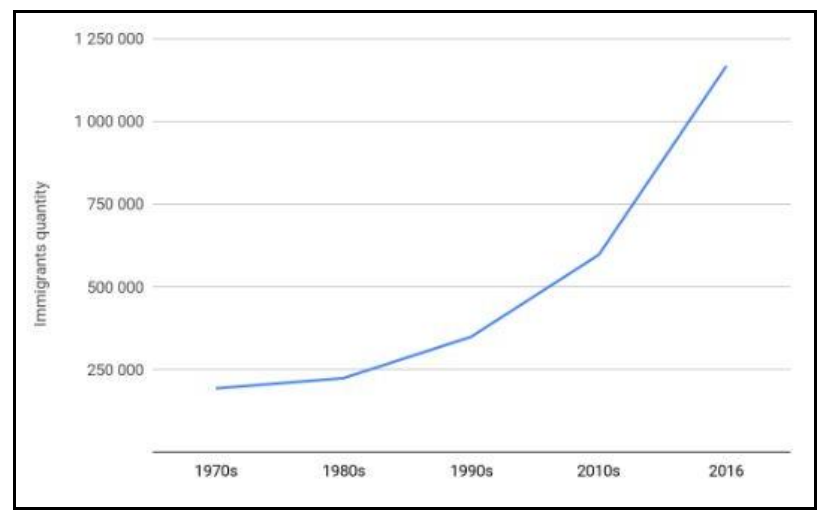

Fig. 3. Increasing of MENA immigrants in the US (1970s - 2016)

In the beginning of 2017, the administration of Donald Trump made several important changes, which affected MENA immigrants' inflow [20]. The entry of nationals from several Muslim-majority countries was barred which limited the fiscal year refugee ceiling of 2017 from 110 thousand people (level set by B. Obama) to 50 thousand. These measures have significantly reduced the influx of migrants. "The number of Syrian refugee arrivals fell from about 15,500 in 2016 to roughly 3,000 in $2017 . "$
We followed how the migration policy of the USA and Great Britain was historically formed. According to statistics, the number of migrants of Arab origin in the United States and Britain is growing steadily. There are several reasons for this; first of all this is an unfavorable economic and political situation in some countries of the Middle East. In addition, the attractiveness of life in countries that are among the world economic leaders. The governments of Great Britain and the USA, in their turn, are trying to resolve this problem and are heading for toughening migration laws.

The scientific novelty consists in the fact that for the first time a comparative analysis of two world migration centers is given in relation to immigrants from the Middle East.

The contribution of each of the authors is as follows: Aleksander Eremin - research topic choosing, data collection and processing, text writing, design and layout; Irina Kuprieva - research structure development, statistical data processing, editing and final approval.

\section{REFERENCES}

[1] C. Vargas-Silva and C. Rienzo, "Migrants in the UK: An Overview", The Migration Observatory at the University of Oxford, 2019. [Electronic resource]. Available at: https://migrationobservatory.ox.ac.uk/resources/briefings/migrants-inthe-uk-an-overview (Accessed: November 2019).

[2] M. Cumoletti and J. Batalova, "Middle Eastern and North African Immigrants in the United States", Electronic resource]. Available at: https://www.migrationpolicy.org/article/middle-eastern-and-northafrican-immigrants-united-states (Accessed: October 2019).

[3] E. Rogan, "The Arabs: A History", Penguin, 2011, 384 p.

[4] G. Orfalea, "The Arab Americans: A History", Olive Branch Press, 2016, 97 p.

[5] S. Tarbush, "Arab engagement in the British general and local elections" [Electronic resource]. Available at: http://thetanjara.blogspot.com/2010/04/british-arabs-and-6-may-generaland.html (Accessed: November 2019).

[6] A. Asuypova, "The formation and development of Muslim communities in Great Britain: the second half of XX - beginning of XXI centuries (Formirovanie i razvitie musulmanskih obshin Velikobritanii: vtoraya polovina 20 - nachalo 21 veka)", PhD Thesis, Moscow, 2011.

[7] S. Shakespeare, "The Arab world: A perspective from Britain" [Electronic resource]. Available at: https://mena.yougov.com/en/news/2017/09/25/arab-world-perspectivebritain (Accessed: October 2019).

[8] S. A. Camarota, "Immigrants from the Middle East, a profile of the foreign-born population from Pakistan to Morocco" [Electronic resource]. Available at: https://cis.org/Report/Immigrants-Middle-East (Accessed: October 2019).

[9] P. Wintour, "Survey reveals scale of hospitality towards Arabs in Britain" [Electronic resource]. Available at: https://www.theguardian.com/uk-news/2017/sep/25/survey-revealsscale-of-hostility-towards-arabs-in-britain (Accessed: October 2019).

[10] US Government immigration regulations [Electronic resource]. Available at: https://www.usa.gov/immigration-and-citizenship (Accessed: October 2019).

[11] A. Ramy, "Thoughts on being Arab in Britain: Multiculti-Schisms" [Electronic resource]. Available at: https://www.plutobooks.com/blog/thoughts-on-being-arab-in-britain (Accessed: October 2019). 
[17] D. Levnev, "US Arab diaspora and its integration in American society (Amerikanskaya diaspora S.SH.A. i eyo integratsia $\mathrm{v}$ americanskoye obshestvo)", Russia and muslim world, may 2012, vol. 251, pp. 109126.

better-read-labours-2015-manifesto-in-full.

[13] D. J. Besharov and Mark H. Lopez, "Adjusting to a World in Motion: Trends in Global Migration and Migration Policy", Oxford University Press; 1 edition, 14 December 2015, 440 p.

[14] A. Sharapov, "UK Immigration policy: legacy of the past and issues of the future (Immigratsionnaya politika Velikobritanii: nasledie proshlogo i problemi budushego)", The contours of global transformations: politics, economics, law, 2010, vol. 3, no. 6, pp. 104-116.

[15] E. Alsultany, "Arabs and Muslims in the media: race and representation after 9/11", New York Press, 2012, 227 p.

[16] D. Voroshilov, "Britain confirms plans to tighten migration system after Brexit (V Britanii podtverdili plani uzhestichit migratsionnuyu sistemu posle Breksit)" [Electronic resource]. Available at: https://ria.ru/20181219/1548274940.html (Accessed: October 2019).

[18] M. W. Suleiman, "The Arab Community in the United States: A Review and an Assessment of the State of Research and Writing on Arab Americans", British Journal of Middle Eastern Studies, April 2010, vol. 37, no. 1, pp. 39-55.

[19] R. Kayyali, "US Census Classifications and Arab Americans: Contestations and Definitions of Identity Markers", Journal of Ethnic and Migration Services, 2013, vol. 39, pp. 1299-1318.

[20] UK Government immigration regulations, [Electronic resource]. Available at: https://www.gov.uk/browse/visas-immigration (Accessed: October 2019). 